\title{
EGG SAMPLING FOR THE WESTERN HEMLOCK LOOPER ${ }^{1}$
}

\author{
By M. G. THOMSON ${ }^{2}$
}

\begin{abstract}
The western hemlock looper will lay eggs in all parts of a tree, but in the years prior to heavy defoliation the greatest number of eggs will be found on the bole in the mid crown. Moss and lichen are the preferred oviposition sites, but many eggs are laid singly in bark crevices. Where ten or more eggs per half-square-foot sample of bark are found in the mid crown, noticeable defoliation may occur in the next summer.
\end{abstract}

\section{INTRODUCTION}

Because the western hemlock looper, Lambdina fiscellaria lugubrosa (Hulst), may cause heavy defoliation and some tree mortality during the year defoliation is first noticed, it is important to determine the population levels of this species in an area as soon as an incipient outbreak is suspected. Since western hemlock looper eggs are laid during September and October and hatch during May and June, this can be done most easily by egg sampling during the winter.

In the past, outbreaks of this insect have frequently gone undetected until after heavy defoliation has occurred, with subsequent extensive tree mortality. In those areas where outbreaks have been anticipated, moths were usually abundant the preceding autumn.

During the 1945 to 1947 outbreaks on Vancouver Island, egg samples were collected along the bole of 165 trees, from breast height to the lower or mid crown. Empty egg shells in samples from 32 trees felled prior to the hatching of the very heavy egg population in 1946 indicated that during the winter preceding the first heavy defoliation, egg samples from the various parts of a tree may average less than five eggs per half square foot. These small numbers give little opportunity to differentiate between endemic populations and incipient outbreaks. By sampling the region of maximum oviposition only, it should be possible, however, to increase the difference between samples of low and epidemic populations.

\section{Methods}

In order to study the egg distribution, trees were felled from 1954 to 1956 in areas where western hemlock looper larvae were noticed. The diameter, height, crown class, length of live crown and percentage of defoliation were recorded and bark samples were collected at breast height and at 10-foot intervals on the bole to the top of the tree. The 6-by-12-inch bark sample used during the 1945-47 outbreak on Vancouver Island was retained, since it could

\footnotetext{
${ }^{3}$ Contribution No. 428, Forest Biology Division, Science Service, Department of Agriculture, Ottawa. Received for publication November 5, 1957.

${ }^{2}$ Forest Biology Laboratory, 409 Federal Building, Victoria, B.C.
} 
be used in sampling the upper part as well as the merchantable length of the bole. It also approximates the one-foot linear limb sample also used between 1945 and 1947.

The eight trees examined in 1954 have been omitted in studying egg distribution since so few of the samples contained eggs. Those that did were mainly from the upper and mid crown. Eight trees near McBride and six on the Big Bend highway, areas with a high larval population in 1955, were felled in October of that year. Four additional trees were felled on the Big Bend highway in May, 1956.

The eggs found were divided by their appearance into several distinct categories-sound eggs laid shortly before the samples were collected; iridescent, pearly translucent egg shells with one end cleanly cut off, from which the larvae probably emerged the previous spring; and mottled brown or discolored eggshells, frequently containing saprophytic growths, from which the larvae had probably emerged prior to the previous winter. In addition, eggs destroyed by parasites or predators, having a ragged or atypical hole on the eggshell and embryonic debris, and old unhatched eggs were also occasionally found. The older eggs were less firmly attached to their resting place than newly laid ones and undoubtedly some had been lost prior to sampling.

\section{Distribution of Eggs on the Host Tree}

The variation in density along the bole of the first three categories of eggs collected in 1955, representative of those laid in 1955, 1954, and prior

\section{TABLE 1}

Distribution of Western Hemlock looper Eggs Along the Bole ${ }^{1}$

\begin{tabular}{|c|c|c|c|c|c|c|c|}
\hline \multirow{2}{*}{$\begin{array}{c}\text { Location of } \\
\text { sample } \\
\text { on bole }\end{array}$} & \multicolumn{6}{|c|}{$\begin{array}{c}\text { Number of eggs per sample } \\
\text { (with probable year laid in parenthesis) } \\
\text { Mean } \\
\text { Median }\end{array}$} & \multirow{2}{*}{$\begin{array}{l}\text { No. } \\
\text { of } \\
\text { Sam- } \\
\text { ples }\end{array}$} \\
\hline & $\begin{array}{c}\text { old egg } \\
\text { shells } \\
\text { (prior to } \\
1954 \text { ) } \\
\end{array}$ & $\begin{array}{l}\text { New eqg } \\
\text { shells } \\
(1954)\end{array}$ & $\begin{array}{c}\text { New eggs } \\
(1955)\end{array}$ & $\begin{array}{c}\begin{array}{c}\text { Old egg } \\
\text { shells } \\
\text { (prior to } \\
1954 \text { ) }\end{array} \\
\end{array}$ & $\begin{array}{l}\text { New egg } \\
\text { shells } \\
(1954)\end{array}$ & $\begin{array}{c}\text { New eggs } \\
(1955)\end{array}$ & \\
\hline \multicolumn{8}{|l|}{ Crown quarter } \\
\hline A (top) & 6.4 & 15.5 & 16.0 & $4-6^{2}$ & $4-5$ & 7 & 12 \\
\hline B & 4.2 & 16.7 & 17.1 & 3 & 13 & 15 & 19 \\
\hline $\mathrm{C}$ & 8.2 & 18.1 & 17.7 & $3-5$ & $7-10$ & 13 & 18 \\
\hline D (bottom) & 2.8 & 8.9 & 7.9 & 0 & 5 & 3 & 17 \\
\hline \multicolumn{8}{|l|}{ Upper half } \\
\hline clear bole ${ }^{8}$ & 1.7 & 8.5 & 6.6 & 0 & 4 & 4 & 15 \\
\hline \multicolumn{8}{|l|}{ Lower half } \\
\hline clear bole ${ }^{3}$ & 2.1 & 7.3 & 4.4 & 1 & $1-2$ & $1-4$ & 12 \\
\hline Breast height & 2.0 & 1.8 & 0.3 & 0 & $0-1$ & 0 & 12 \\
\hline
\end{tabular}

${ }^{1}$ Based on 6- by 12-inch bark samples.

There there is an even number of samples in a category, the number of eggs in each of the two middle samples is shown.

${ }^{2}$ Half of the clear bole from the base of the crown to breast height. 
to 1954 respectively, is shown in Table 1 . The frequency distribution of the number of eggs per sample at each tree position was skewed to the left. Thus a more accurate impression of the peaks of the distributions can be obtained from the medians than from the means. For not only does the median show the mid-point of an ordered series, but it also indicates the relative position of the mode, or most frequent sample size, since in such distributions the median lies between the mode and the mean and approximately one-third the distance away from the latter.

The number of eggs per sample was low, as had been anticipated from previous sampling. The greatest density of eggs of all ages was found in the middle and upper parts of the crown. The trees sampled in 1955 ranged in height from 64 to 98 feet and had a mean height of 84 feet. The start of the base of the live crown varied from 11 to 45 feet. The average was 25 feet. A large number of the samples at breast height and from below the live crown contained no eggs. It would thus appear inadvisable to restrict samples to the base of standing trees as has been suggested (1) during the initial years of an outbreak. This may not be so critical during subsequent years, since the population levels are usually much higher then.

As a further check on the distribution of eggs within the crown, four trees were felled on the Big Bend in May, 1956. The live crowns were quartered and whole branches from each of the top three quarters were removed, cut in half and examined for eggs. The bottom quarters were not sampled in view of the large size of the branches and since the previous data indicated that the egg density would likely be less there than in the upper quarters. In addition to the branch samples the regular bole samples and all the information collected previously were gathered as well. The total number of eggs for all years found in the various samples are shown in Table 2. Tree No. 1 had the lightest and Tree No. 4 the heaviest population. When it is considered that the number of eggs recorded for the bole samples is for one-half square foot of bark only, while that for the branch samples is for the entire inner or outer half of a branch, including needles and twigs, it is obvious that the greatest amount of oviposition occurs on the bole in the mid crown.

The most sensitive indication of the population level should be obtained if sampling is restricted to the mid-crown region. This is in line with the habits of the species. Gravid females are weak fliers and probably lay most of their eggs near their emergence site. Pupal cases in the bark and branch samples were densest in the mid-crown region. Larval activity probably is also concentrated in the upper parts of the crown since this is the region where defoliation is first noticeable. Although they are more abundant in the mid-crown region, the fact that the eggs may be deposited in all parts of the tree, rather than being restricted to certain areas, helps to explain the possibility of large populations being present even though the number of eggs per sample is small.

\section{VIABILITY OF EgGS}

Another factor contributing to the possibility of high larval populations when the number of eggs per sample is low is the small amount of egg mortality during the early years of an outbreak. In six of seven different areas between 


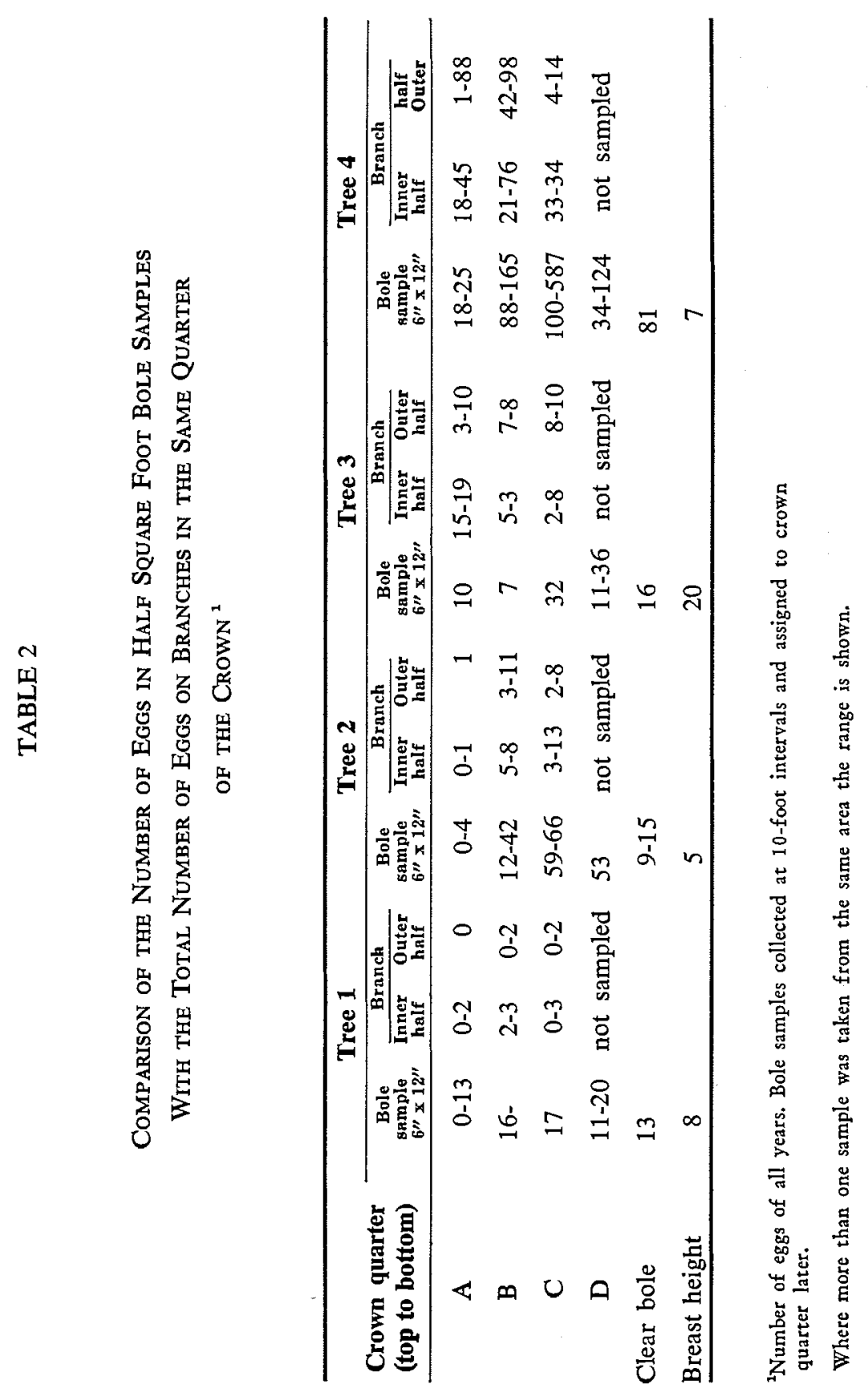


85 and 95 per cent of the eggs hatched (Table 3 ). The exception was the high populations on the Big Bend during 1945-46 which, however, did not cause the patches of dead timber typical of a severe hemlock looper outbreak.

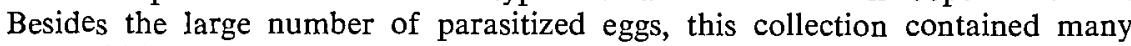
eggs which, from their appearance, were unfertilized.

TABLE 3

Egg Mortality During Some Western Hemlock looper Outbreaks ${ }^{1}$

\begin{tabular}{|c|c|c|c|c|c|c|}
\hline Winter & Place & $\begin{array}{l}\text { Year of } \\
\text { outbreak }\end{array}$ & $\begin{array}{l}\text { No. of } \\
\text { eggs }\end{array}$ & $\begin{array}{c}\text { Per cent } \\
\text { egge with dead } \\
\text { cmbryos or } \\
\text { unfertilized }\end{array}$ & $\begin{array}{l}\text { Per cent } \\
\text { parasitized } \\
\text { eggs }\end{array}$ & $\begin{array}{c}\text { Per cent } \\
\text { eggg } \\
\text { hatehed }\end{array}$ \\
\hline $1928-29$ & Indian River & 2nd & 1380 & ( 13.7 & 7 ) & 86.3 \\
\hline $1937-38$ & Trout Lake & $2 \mathrm{nd}$ & 5679 & 14.8 & 0.0 & 85.2 \\
\hline $1945-46$ & Nitinat & 2nd & 4135 & 6.1 & 0.0 & 93.9 \\
\hline $1945-46$ & Sarita & 2nd & 1664 & 10.8 & 0.0 & 89.2 \\
\hline $1945-46$ & Big Bend & 2nd & 2644 & 41.9 & 30.6 & 27.5 \\
\hline $1954-55$ & McBride & $1 \mathrm{st}$ & 1136 & 4.1 & 0.5 & 95.4 \\
\hline $1954-55$ & Big Bend & $1 \mathrm{st}$ & 356 & 3.8 & 7.0 & 89.2 \\
\hline
\end{tabular}

${ }^{1}$ Based on records of the Forest Biology Laboratories in British Columbia.

\section{Egg Laying Sites}

To facilitate the examination of future samples a record was kept of the location of the eggs found, to determine the preferred medium for egg laying. A fine hair-like black lichen occurred more frequently in the McBride area than on the Big Bend and, where present, appeared to have the greatest density of eggs, although the surface area was very restricted. A pale yellowgreen branching lichen was much more common. It also harbored many eggs, including most of those found on the branches. The greatest number of eggs, however, were found singly in bark crevices both on the bole and on the limbs. Only two of 84 samples had any eggs on the bark surface and only one on twigs. No eggs were found on the needles, although in the past eggs have been observed on needles by members of the laboratory. Very little moss was found on the sample trees in the Interior but on the Coast moss replaced lichen as the favored oviposition site.

\section{Egg Population In Relation To Defoliation}

Little is known about the level of western hemlock looper egg populations just prior to the start of severe defoliation. The following brief review based on the Annual Reports of the Ranger for the Prince George Forest Biology Ranger District will indicate, however, the order of magnitude and the rate of change of population levels. In 1950 the western hemlock looper was very scarce in British Columbia east of the Coast Mountains. Larvae were found in only three of the three hundred odd collections made within hemlock stands that year. (A collection consists of all the larvae beaten on to a 7- by 9-foot sheet spread in turn under three small trees.) Then from 1951 onward there was a gradual increase throughout the region. By 1953 
the populations had risen to a mean of 55 larvae per collection south of McBride. In 1954 the mean there increased to 156 and in 1955 it was 563 larvae per collection. No defoliation was noticed in this area prior to 1955 but during that year an area $3 / 4$ mile long by $1 / 4$ mile wide was severely defoliated and a belt $1 / 2$ mile wide and 2 miles long was visibly damaged. Heavy defoliation did occur, however, in several nearby areas in 1954. The number of larvae per collection in these areas was lower in 1953 than in those at McBride.

Two trees were felled near McBride in August, 1954, prior to adult emergence, and bark samples taken at various heights to compare the 19531954 egg population with those of the 1954 larval samples mentioned above. Only five eggs were found in eight samples. A single egg was found in one of the two mid-crown samples.

Of the eight trees from this area felled in October, 1955, and included in Table 1, half were from the center of the outbreak and half from near the periphery. Samples on these trees from within fifteen feet of the center of the live crowns, have been pooled and compared with the degree of defoliation of the sample trees (Table 4). From these data one might expect that severe defoliation would occur if there was an average of 30 or more viable eggs per mid-crown sample; severe defoliation can occur at lower egg densities, however, since two trees with a mean of only 15 eggs per sample were defoliated 85 per cent. As a comparison, only nine eggs were found in the

TABLE 4

Egg Density at Mid Crown and Subsequent Defoliation, McBride, 1955

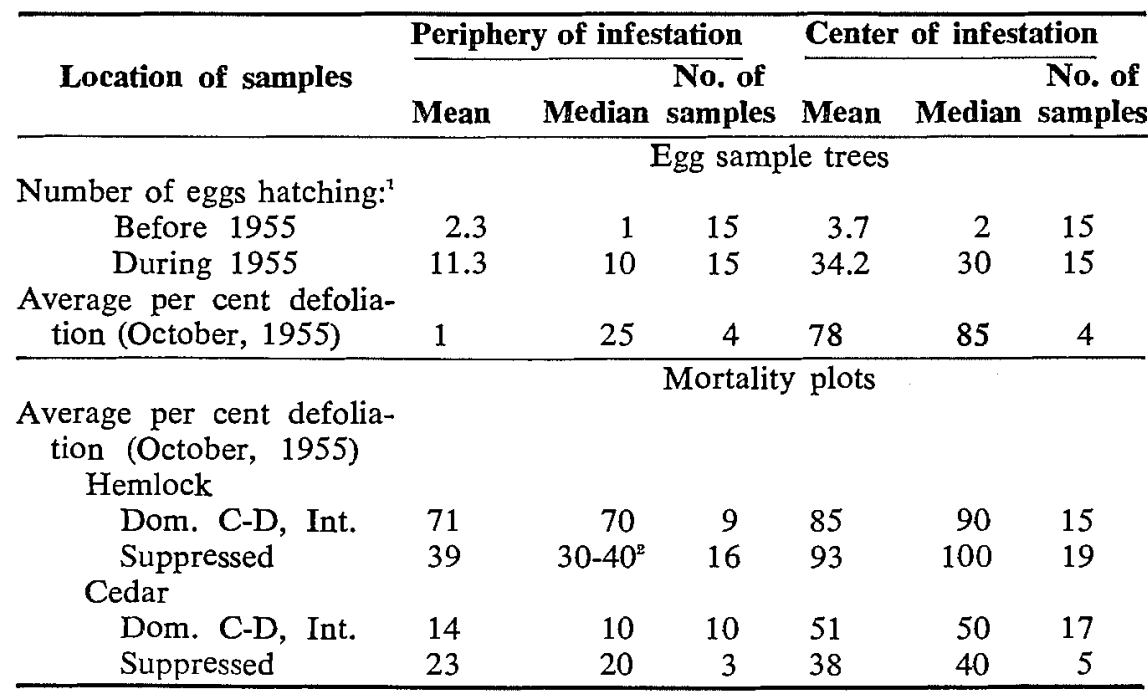

${ }^{3}$ One-half square foot samples in mid crown.

Number of eggs in each of the two middle samples. 


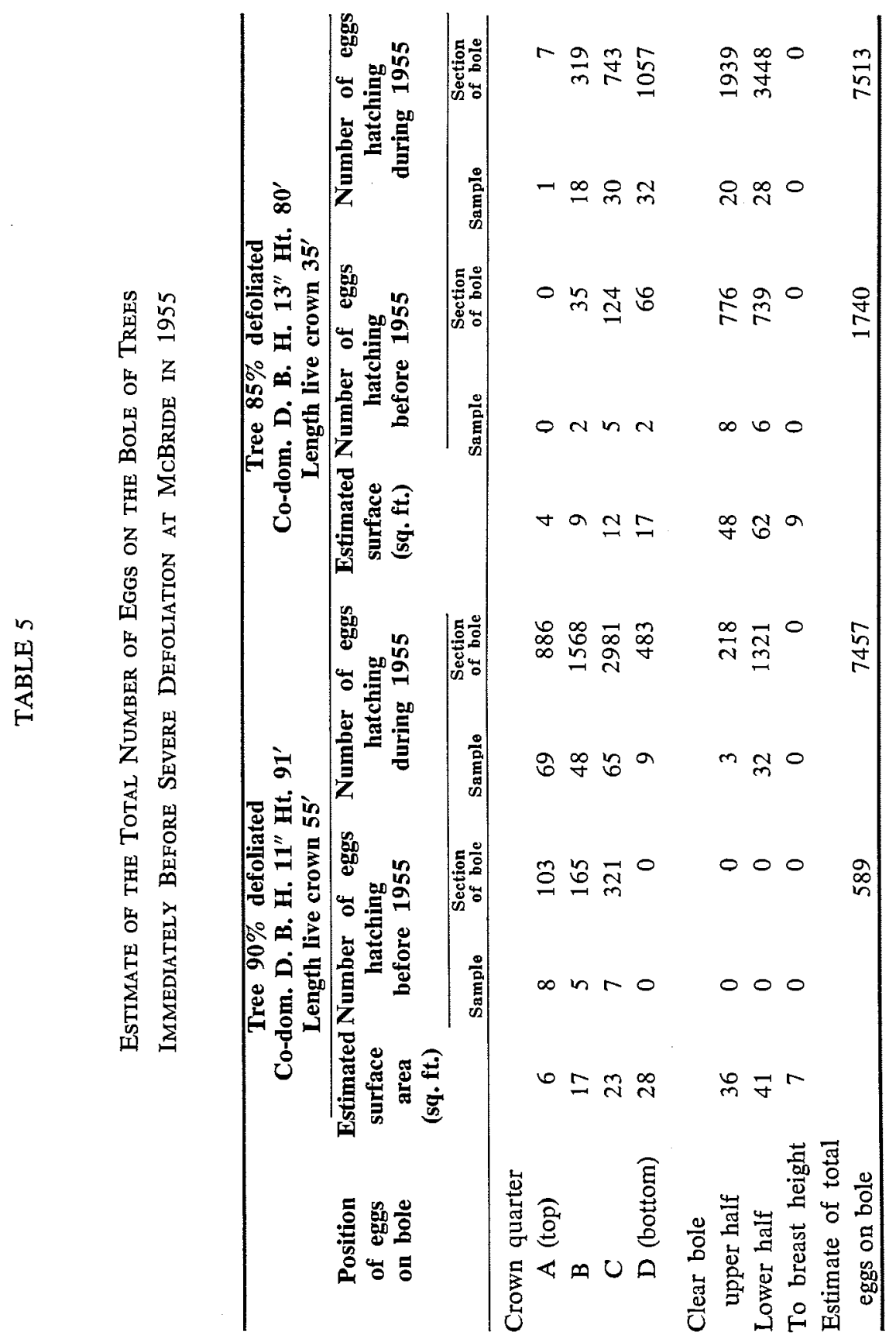


four breast height samples from the center of the infestation. Data from two mortality plots established at the same time, but not contiguous to the egg sample trees, are also included in the table to provide more information on the defoliation in the region.

An indication of the population level in the stand associated with these sample sizes may be obtained by considering that the average sample size of each section of the bole represents the true average for that section and that the bark surface of each section is frustrum of a right cone. The total number of eggs on the bole of the trees in the center of the infestation estimated on this basis is shown in Table 5. Assuming 50 trees per acre, this would mean a population of about 50,000 eggs per acre immediately prior to 1955 and about 375,000 per acre hatching in 1955 on the boles alone not counting those on the branches and duff.

The trees sampled during the 1945-47 outbreak on Vancouver Island were much larger than those examined more recently in the interior of the Province and the length of clear bole was much greater. An indication of the initial egg density in this area can be obtained from the trees felled between October, 1945, and April, 1946. Of the 32 trees examined, 17 were defoliated 50 per cent or more. The number of eggs laid prior to the 1945 defoliation in mid-crown samples of a tree 95 per cent defoliated and one 85 per cent defoliated was 59 and 16 respectively, similar to that of trees with the same degrees of defoliation at McBride. The density of the samples from the remaining trees is shown in Table 6. These latter trees ranged from 50 to 160 feet in height. The average was 121 feet. In addition, the number of eggs laid immediately after the 1945 defoliation on these same trees is also included in Table 6. These latter figures indicate the rate of population increase and also show that with the heavy defoliation and higher populations a proportionally larger number of eggs are laid at the base of the tree and on the clear bole. When defoliation becomes heavy the larvae are much more rest-

\section{TABLE 6}

Total Number of Eggs laid in One-Half Square Foot Samples on Trees Defoliated Fifty to Seventy-five Per Cent in 1945 ON VANCOUVER ISLAND

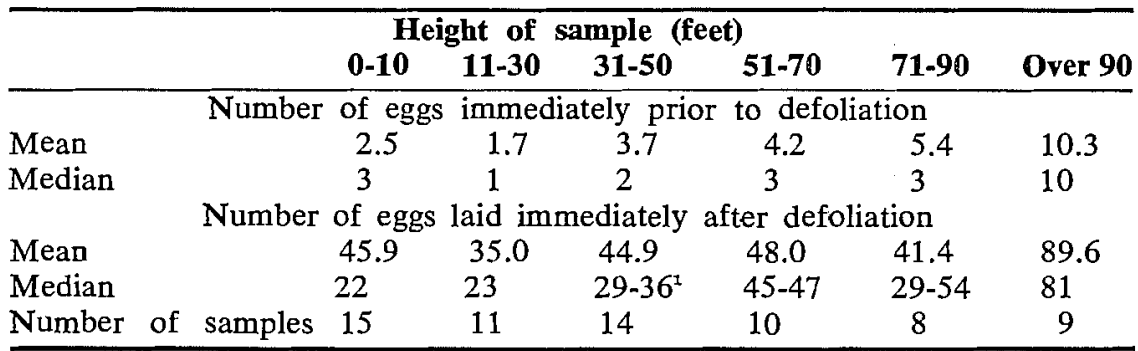

${ }^{1}$ Where there is an even number of samples of a category, the number of eggs in each of the two middle samples is shown. 
less; many drop to the ground and pupate there, on the lower portions of the boles, or on brush. This probably accounts for the more uniform distribution of the eggs in the second year of the outbreak.

\section{RECOMMENDATIONS}

It is recommended that future western hemlock looper egg sampling be restricted to the bole in the middle of the crown and that co-dominant trees be included in the sampling, since the population may be concentrated in the overstory. Until more is known about the relationship between the number of eggs per sample and the degree of subsequent defoliation, it would be advisable to watch those stands where ten or more eggs per half-square-foot sample are found. Those stands with 20 or more eggs per sample will probably be heavily defoliated in the following summer unless the population is reduced in the interval. Where it is uncertain whether control operations are warranted or not, a watch should be kept for the first sign of defoliation, since an estimate of the final defoliation to be expected at the end of the year can be made from the degree of defoliation and the stage of larval development when discovered (2). Three quarters of the feeding takes place during the fifth instar, usually during the latter part of July. Where control operations are planned they should be carried out before this period.

\section{REFERENCES}

1. KINGHORN, J. M. 1952. Western hemlock looper egg sampling. Canada, Dept. Agric., For. Biol. Div., Bi-Monthly Prog. Rept. 8(3): 3-4.

2. THOMSON, M. G. 1957. Appraisal of western hemlock looper infestations. For. Chron. 33: 141-147. 